\title{
Spawning-Age Differences and their Temporal Trends in Wild and Sea-Ranched Atlantic Salmon Stocks, from Stock Mixture Data
}

\author{
Irma Kallio-Nyberg ${ }^{1, *, \#}$, Marja-Liisa Koljonen ${ }^{2}$ and Irma Saloniemi ${ }^{3}$
}

\author{
${ }^{I}$ Finnish Game and Fisheries Research Institute, Korsholmanpuistikko 16, FI-65100 Vaasa, Finland; ${ }^{2}$ Finnish Game \\ and Fisheries Research Institute, P.O. Box 2, FI-00791 Helsinki, Finland; ${ }^{3}$ University of Turku, Department of Biology, \\ Laboratory of Genetics, FI-20014 Turku, Finland
}

\begin{abstract}
Origin and age was determined for individual fish caught in offshore catches of Atlantic salmon stocks (Salmo salar L.) in the Baltic Sea over the years 2000-2009. DNA microsatellite loci and smolt age were used to probabilistically assign returning spawners to their stock of origin. Data for this study were based on approximately 2600 catch samples of the five most common wild and four sea-ranched, hatchery-reared stocks. Spawning age, and sex ratio differed both within and between these wild, and sea-ranched groups. The females were mainly $(78.7 \%)$ two sea-winters old and the males usually $(68.7 \%)$ only one sea-winter old. In both sexes, the mean age at maturity was lower in the hatchery-reared, sea-ranched stocks than in naturally reproducing stocks. In the 2000 s, there was a weak decreasing trend in the male spawning age, but not in that of females. The sex-ratio of the spawners was female dominant in the naturally reproducing stocks, but male dominant in hatchery-reared stocks. Published historical data from two of the same rivers suggest that the majority of males were multi-sea-winter spawners in the 1930s, and variation in the age distribution of the spawners has become narrower and skewed towards a younger age in the present data (2000-2009) compared to the earlier situation.
\end{abstract}

Keywords: Baltic sea, genetic mixed stock analysis, individual assignment, Salmo salar, sea age at maturity, sex.

\section{INTRODUCTION}

The spawning age, or age at maturity, of the anadromous Atlantic salmon (Salmo salar) is a heritable trait, and its variation has been shown to have adaptive components [1]. The homing of salmonids to their natal river has led to adaptation to local environmental conditions $[2,3]$. Spawners of a large river are known to be older and larger than those of a small river, as fish size is a response to the discharge of the river, and to the distance to the feeding areas in the sea [4-7].

Because the growth rate and spawning age of salmonids are negatively correlated [8], selection favoring growth tends to lower the spawning age. In addition to the genetic background, environmental factors in the sea affect the number of years spent on the feeding migration before maturation [9, 10]. The spawning age of Atlantic salmon varies from one to five years, calculated as the number of winters spent in the marine feeding areas after their two to five freshwater years in the river $[11,12]$. Occasionally, salmon are able to recover from their first spawning and return to the sea, and even spawn for a second time $[5,13,14]$, but in the Baltic Sea the proportion of such fish is currently only a few percent [15].

*Address correspondence to this author at the Finnish Game and Fisheries Research Institute, Korsholmanpuistikko 16, FI-65100 Vaasa, Finland; Tel: +358 295327 678; E-mail: irma.kallio-nyberg@luke.fi

\#The Finnish Game and Fisheries Research Institute will merge with MTT Agrifood Research Finland, the Finnish Forest Research Institute and the statistical services of the Information Centre of the Ministry of Agriculture and Forestry Tike on 1 January 2015, to form Natural Resources Institute Finland.
As a nearly semelparous fish, the final body size of the Atlantic salmon depends on its age at maturity. In the Baltic Sea, the size of one-sea-winter (1 SW) fish in the catch is about $60-65 \mathrm{~cm}$, while that of three-sea-winter ( $3 \mathrm{SW})$ fish is about $95-100 \mathrm{~cm}$ [16]. Body size is important from the perspective of both fisheries management and the conservation of viability. Large fish increase the commercial value of the catch, but besides this, the spawning size is also an important evolutionary trait related to fecundity and the fitness of individuals and the population as a whole [17]. Small females, in particular, produce fewer, smaller, and weaker eggs than large females, and thus a change in the female spawning size may reduce the fitness of the whole population. The collapse of the Atlantic cod (Gadus morhua) stock is a famous example of fisheries selection leading to a decreased spawning age and thus also body size $[18,19]$.

Hatchery rearing is likely to affect the spawning age, reduce fitness in the wild, and have adverse effects on several adaptive traits in salmon [20]. Hybridization of reared and wild fish may also change the spawning age and other lifehistory traits of the stocks [21-24]. Domestication selection in hatcheries tends to favor a high growth rate and early sexual maturity $[21,25,26]$, and fisheries usually select against a large size and later spawning age [27-29]. A trend towards younger spawners was observed in the $20^{\text {th }}$ century for many salmon stocks, as a marked decline in either the proportion of older, multi-sea-winter (MSW), or of repeatedly spawning salmon [30-32]. These trends have also been reported in Baltic Sea salmon $[15,33]$.

The estimated natural production of salmon smolts is below the potential level in many Baltic Sea rivers [34], and 
many salmon stocks have been lost because of the dredging and damming of rivers for hydropower production since the 1940s. Salmon stocks originating from the currently closed rivers have been maintained by rearing offspring from both hatchery broodstocks and sea-ranched parents [16]. Since the 1980 s, fishing pressure has been heavy, and it has threatened the naturally reproducing stocks $[12,15,35,36]$. In addition, since the 1990s, high post-smolt mortality for unknown reasons has impaired the state of the natural stocks [26, 37-39]. Changes in adaptive traits such as a decrease in the spawning age and size may constitute further risks to the viability of the remaining wild stocks.

Here, we analyzed stock-specific spawning ages from sea-caught fish by first identifying the stock of origin of individual fishes with a genetic individual assignment method, and then using this stock identity to define the stock-specific spawning age distributions of the nine Atlantic salmon stocks most commonly contributing to the catches. Our study approach allowed us to reveal previously unknown differences in spawning age, which is an evolutionarily important, adaptive quantitative trait and usually varies among river stocks of Atlantic salmon. In addition, we were able to analyze two time intervals, trends during a ten-year period in contemporary stocks, and also historical changes since the 1930s for two stocks for which historical information was available. Although genetic differentiation in adaptive qualitative traits is in theory known to occur, reports on these differences are rare, and yet they have evolutionary significance. Atlantic salmon stocks are a target of many types of human interference, and are thus likely to change genetically because of this, in addition to changes caused by varying natural selection pressures.

The goal of this study was to describe stock-specific spawning age distributions, their potential differences, and also the changes over time, from 2000 to 2009, in five wild (Tornionjoki Wild, Simojoki, Kalixälven, Byskeälven, Vindelälven) and four hatchery-reared (Tornionjoki Hatchery, Iijoki, Oulujoki, Luleälven) Atlantic salmon stocks (Fig. 1). The Tornionjoki salmon stock had both a wild and searanched component. In addition, we compared data from the 1930 s, available from one of the current wild stocks (Kalixälven) and one of the current hatchery-reared stocks (Luleälven) when they were both still wild [40], with information on these same stocks in their contemporary state. These historical samples were taken before the offshore fishery or hatchery rearing had started. The potential causes of the observed differences and changes were examined in relation to their reproduction (hatchery) histories.

\section{MATERIAL AND METHODS}

\section{Annual Sampling of the Spawners}

In total, 7414 returning salmon were sampled by fishermen during May to July in 2000 and in 2002-2009 from the salmon catches in the northern Baltic Sea. The sampling areas corresponded to ICES subdivisions 29, 30, and 31 (Fig. 1) along the spawning migration route of the fish from the Baltic Main basin to the northern the Gulf of Bothnia (GB):

1) the Aland Sea ( $\AA S$ ), subdivision 29; samples mainly taken in week 22;
2) the Bothnian Sea (BS), subdivision 30; mainly sampled in week 25; and

3) the Bothnian Bay (BB), subdivision 31; mainly sampled in week 26 (Fig. 1).

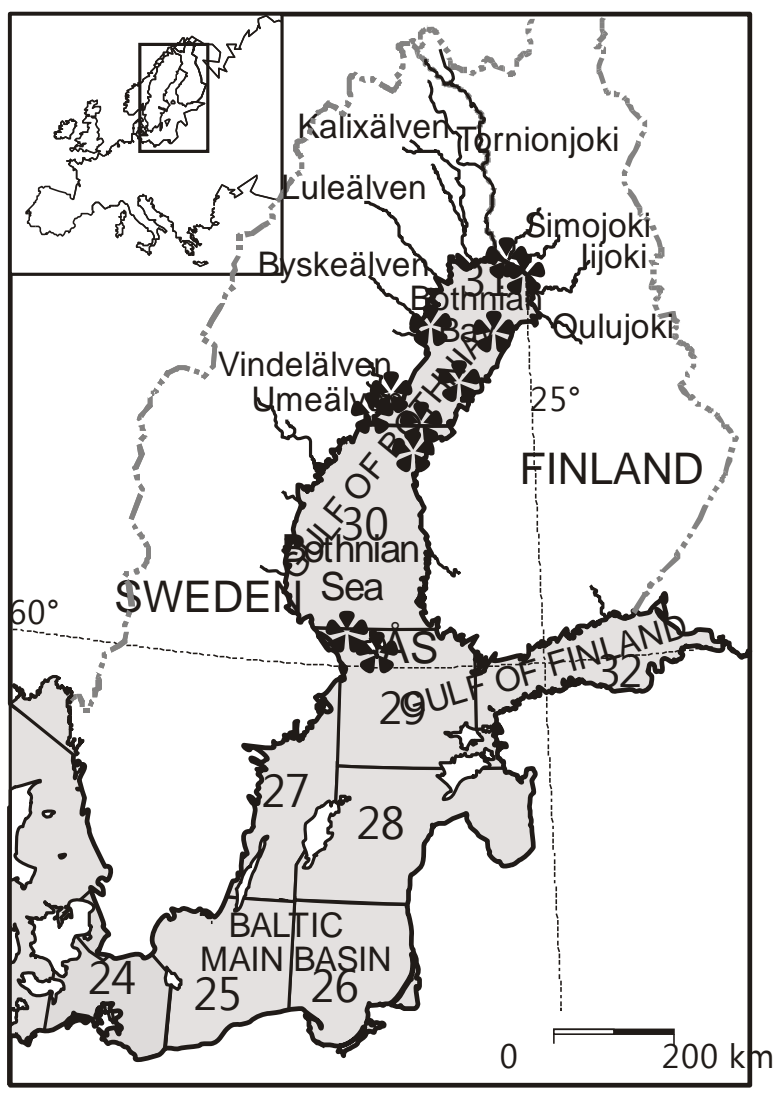

Fig. (1). Map of the Baltic Sea showing the Bothnian Bay rivers and the sampling sites $(*)$ in Finnish and Swedish coastal waters in the Åland Sea ( $\mathrm{S})$, the Bothnian Sea, and in the Bothnian Bay.

The catch length (individual total length) and the sex of the fish, as well as the catch date and site, were recorded on capture, and scale samples were taken from each fish for DNA analysis and age determination. Both the freshwater years and sea winter years were separately determined from scales. The freshwater age information was used as one variable in individual assignment.

As all captured individuals were migrating towards river mouths in order to spawn in the autumn of the same year, the sea age and the age at maturity or spawning age were in this case the same. Information on the sex was not available for all individuals, but those without this information were excluded from the analysis. In practice, all of the studied fish $(99.99 \%)$ were first-time spawners.

Catch samples were collected from the coastal trap net and driftnet fishery, along the spawning migration route from the Baltic Main Basin towards the northern spawning rivers. The data were pooled over ten years for each stock to analyze the mean spawning age distribution. Thus, annual variation in the spawning migration is not assumed to affect 
the results. The spawning migration lasts only a limited time and peaks in June. For each site, the peak week could even be defined (see above). The sampling covered the whole fishing season. The estimated stock group proportions from the first five years (2000-2005) from the same catches have previously been published [34]. A comparison of the present situation with the situation $70-80$ years ago was possible by making use of data on Luleälven and Kalixälven salmon stocks published by Alm [40].

The legal minimum landing size of Atlantic salmon in the Baltic Sea is generally $60 \mathrm{~cm}$. However, in the Bothnian Bay, where the majority of fish from all studied stocks were caught (65\%-91\%) (Table 2), the legal minimum landing length is $50 \mathrm{~cm}$ (since 1993) [37], thus also allowing the smallest mature males to be caught.

\section{Salmon Stocks}

Five wild and four reared and sea-ranched salmon stocks, which were the most abundant stocks in the catches, were chosen for the current study (Table 1). The home rivers of all these stocks drain into the Bothnian Bay, the northernmost part of the Baltic Sea, and the stocks have very similar migration patterns. The fish from all these stocks undertake their feeding migration to the Baltic Main Basin, and return as spawners to their home rivers early in the summer, mainly during a few weeks in June $[6,25]$.

The spawning environment and its selective factors differ between the wild and the sea-ranched hatchery stocks, but the conditions and feeding areas in the sea are common to all fish, so the observed differences between wild and searanched groups are assumed to be a result of either direct differences in the reproduction environment or the genetic selection it causes [6].

The Tornionjoki River is the border river between Finland and Sweden. It supports a wild, naturally reproducing salmon stock (referred to here as Tornionjoki W salmon). Smolt production collapsed in the 1980s [12], but the stock has now recovered (Table 1). The northernmost spawning sites are located about $500 \mathrm{~km}$ from the river mouth [41].

Reared Tornionjoki (Tornionjoki R) salmon smolts have been released both into their home river [12] and into the nearby Kemijoki estuary [16] (Table 1). The broodstocks are established from fish caught in the wild [42].

The Simojoki salmon is the other wild Finnish salmon stock on the Baltic Sea coast. It was near extinction in the 1980s [36]. Following supportive stockings, restoration of the river, and fishing regulation, the status of the stock has improved [12, 15, 36].

The Iijoki salmon has been maintained as a broodstock since the 1960s, when the river was dammed for hydroelectric power production. The reared smolts have mainly been produced by using broodstocks that were originally founded from fish of the river before it was dammed [43]. The number of successive hatchery generations was 4.5 in 1995 [44]. More recently, ascending spawners have been used as parents for broodstocks [42]. The loss of the natural smolt production of the Iijoki salmon has been compensated for by annual smolt releases into the estuary of the river (Table 1).
The Oulujoki salmon is a reared mixed stock including genetic material from at least the Finnish Iijoki, Tornionjoki, and Oulujoki, and the Swedish Skellefteälven stocks [45]. The natural salmon run of the Oulujoki salmon ended in the 1960 s, when the river was dammed. The number of successive hatchery generations was seven in 1995 [44]. To compensate for the lost smolt production, 100000 reared smolts are annually released into the estuary [43].

The Kalixälven River supports a natural salmon stock (Table 1). Together with the Tornionjoki River, this river maintains the two largest wild salmon stocks within the Baltic Sea range.

The Luleälven salmon is currently a reared hatchery stock. The loss of natural smolt production has been compensated for by the annual release of 540000 smolts [46] (Table 1). The production of smolts is based on the annual capture of spawners from the river mouth.

The Byskeälven salmon is a Swedish wild salmon stock (Table 1).

The Vindelälven River supports a natural salmon stock. It is a tributary of the River Umeälven. The Umeälven salmon is a hatchery stock, and regular annual releases (94 000 smolts) are carried out with this stock [46] (Table 1).

\section{Identification of the River Stock of Origin}

Freshwater age distributions and multilocus genotype frequencies at 17 DNA microsatellite loci in baseline stocks and catch samples were used to estimate the stock composition of the catches and the stock of origin of individual fish. For the freshwater age, or smolt age, two age classes were used: either 1- and 2-year-olds (Type 1) or older smolts (Type 2). This classification was used as one variable in the analysis, similarly to a previous investigation [47].

In addition to the eight microsatellite loci used in Koljonen (2006) [34], a further nine loci were analyzed to increase the total number to 17 , so that variation was determined at the following 17 microsatellite loci: (1) SSa14 [48], (2) SSa171 [49], (3) Ssa197 [49], (4) SSa202 [49], (5) SSa289 [48], (6) SSa407 [50], (7) SSa85 [48], (8) 8SSaD157 [51], (9) SSos1417 [52], (10) SSosl438 [52], (11) SSos185 [52], (12) SSsp1605 [53], (13) SSsp2201 [53], (14) SSsp2210 [53], (15) SSsp2216 [53], (16) SSsp3016 [53] and (17) SSspG7 [53]. In addition to catch data, the same freshwater age distribution and DNA microsatellite data for 17 loci were available for all potentially contributing stocks, or baseline stocks [47].

The polymerase chain reaction (PCR) and DNA labeling were performed as described in Säisä et al. [54]. Microsatellite genotypes were detected with an Applied Biosystems ABI 3130 automated DNA sequencer and analyzed with GENEMAPPER Analysis Software version 4.0, with the size standard of Applied Biosystems GeneScan 500LIZ. Automatic outputs were checked manually. The same set of 17 DNA microsatellite loci was also used in the catch analysis of Vuori et al. [55].

The Bayesian estimation method for mixed stock analysis was used in the calculations performed with the BAYES program [56]. Genetic information on 33 Atlantic salmon 
Table 1. Current (2010) natural smolt production levels for the five wild Atlantic salmon stocks and the number of annually released smolts for the four hatchery stocks included in the analysis $[37,46]$.

\begin{tabular}{|c|c|c|c|c|c|}
\hline No & River stock & Country & Propagation & $\begin{array}{c}\text { Natural smolt } \\
\text { production }\end{array}$ & Released smolts \\
\hline 1 & Tornionjoki, W & Finland, Sweden & Wild & 1000000 & - \\
\hline 2 & Tornionjoki, H & Finland & Hatchery & - & 615000 \\
\hline 3 & Simojoki & Finland & Wild & 36000 & - \\
\hline 5 & Oulujoki & Finland & Hatchery & - & 100000 \\
\hline 6 & Kalixälven & Sweden & Wild & 700000 & - \\
\hline 7 & Luleälven & Sweden & Hatchery & - & 540000 \\
\hline 8 & Byskeälven & Sweden & Wild & 100000 & - \\
\hline
\end{tabular}

Table 2. The mean proportion (as a percentage) over nine years (2000-2009) of nine Atlantic salmon stocks in the catches from three Baltic Sea areas: ICES sub-divisions 29 (Åland Sea), 30 (Bothnian Sea), and 31 (Bothnian Bay) (Fig. 1), when the threshold value for correct individual assignment $(P>0.59)$ was applied. The sample size $(n)$ is presented for each stock.

\begin{tabular}{|l|c|c|c|c|}
\hline River stock & Åland Sea \% & Bothnian Sea $\%$ & Bothnian Bay \% & 67 \\
\hline \hline Tornionjoki W & 8 & 25 & 65 & 738 \\
\hline Kalixälven & 12 & 23 & 91 & 201 \\
\hline Byskeälven & 4 & 5 & 67 & 105 \\
\hline Vindelälven & 6 & 27 & 77 & 99 \\
\hline Simojoki & 1 & 22 & 86 & 416 \\
\hline Tornionjoki H & 5 & 6 & 89 & 276 \\
\hline Iijoki & 2 & 12 & 68 & 281 \\
\hline Oulujoki & 1 & 17 & & 142 \\
\hline Luleälven & 15 & 59 & \\
\hline
\end{tabular}

stocks around the Baltic Sea was available as baseline stock data for the catch analysis [34]. Of these, 20 were stocks of rivers draining into the Bothnian Bay and having stocks that could occur in the analyzed catches. In all, 20 chains were run for the posterior probability distributions for each catch sample for all the Gulf of Bothnia samples over the years. The prior of each potential baseline stock had a maximum proportion of $82.5 \%$ in turn, and the others evenly $0.05 \%$. The convergence of the chains to the posterior probability distribution was tested and approved for each catch sample with convergence statistics [57], included in the BAYES software package. The last $1000 \mathrm{MCMC}$ iterations of each 5000 -iteration chain were combined and used to describe the posterior probability distributions of the proportions of each baseline stock, and correspondingly to estimate the probability of each individual fish belonging to any of the baseline stocks. Additional details of the baseline stocks and estimation method are provided in Koljonen [34], Koljonen et al. [58], and [37].
Only fish assigned to the nine northernmost stocks were included into this study (Table 3), as their numbers were large enough to allow partitioning into several age classes. In order to reduce the level of uncertainty related to individual assignments, only individuals with a probability of correct source assignment above 0.59 were included in the current analyses. With this threshold value, the probability of the next likely stock was on average only $0.12 \pm 0.11(n=2583$, Table 3), meaning that the second best stock candidate was no longer very likely to be correct, and cases with very similar probabilities for two stocks were excluded. The probability for the third best stock candidate was in this case only 0.02. Altogether, 2583 fish with complete sex and sea age information were assigned to these nine stocks when using the threshold probability value of 0.59 . After this, the mean probability of correct individual assignment for all nine stocks was $0.85( \pm 1.13$; see Table 3$)$, and varied from 0.8 to 0.9 . 
Table 3. Salmon stocks, and their sample sizes $(n)$ with the threshold level of correct individual assignment $P>0.59$. The mean probability of correct individual assignment of the first (P1), second (P2), and third (P3) source stock of origin is shown, and the sex ratio (the proportion of males) for the same data.

\begin{tabular}{|l|c|c|c|c|c|}
\hline $\begin{array}{l}\text { Stock, wild (W) or } \\
\text { hatchery (H) }\end{array}$ & $\begin{array}{c}\boldsymbol{n} \\
\mathbf{P} \mathbf{0 . 5 9}\end{array}$ & Mean P1 & Mean P2 & Mean P3 & $0.02 \pm 0.03$ \\
\hline \hline Tornionjoki, W & 738 & $0.83 \pm 0.12$ & $0.14 \pm 0.11$ & $0.02 \pm 0.03$ & 0.43 \\
\hline Kalixälven, W & 325 & $0.79 \pm 0.12$ & $0.18 \pm 0.11$ & $0.03 \pm 0.04$ & $0.02 \pm 0.03$ \\
\hline Byskeälven, W & 201 & $0.85 \pm 0.13$ & $0.11 \pm 0.10$ & $0.04 \pm 0.04$ & 0.46 \\
\hline Vindelälven, W & 105 & $0.90 \pm 0.11$ & $0.07 \pm 0.08$ & $0.03 \pm 0.03$ & 0.58 \\
\hline Simojoki, W & 99 & $0.83 \pm 0.13$ & $0.11 \pm 0.10$ & $0.11 \pm 0.09$ & 0.60 \\
\hline Tornionjoki, H & 416 & $0.83 \pm 0.13$ & $0.08 \pm 0.08$ & $0.03 \pm 0.03$ & 0.69 \\
\hline Iijoki, H & 276 & $0.88 \pm 0.12$ & $0.06 \pm 0.08$ & $0.03 \pm 0.04$ \\
\hline Oulujoki, H & 281 & $0.91 \pm 0.12$ & $0.09 \pm 0.08$ & $0.12 \pm 0.11$ & 0.54 \\
\hline Luleälven, H & 142 & $0.86 \pm 0.12$ & $0.85 \pm 0.13$ & & 0.03 \\
\hline Total & 2583 & & & 0.03 \\
\hline
\end{tabular}

Although some uncertainty remained in the individual assignment, the method identified the stocks consistently and coherently over the years [37]. The remaining uncertainty only tends to mix the populations and thus reduce the potentially observable differences. This same individual assignment method has been used by Palm et al. [58] and Vuori et al. [55] with the whole range of individual assignment probabilities. Moran et al. 2014 [59] tested the use of probability threshold values in a similar approach, when analyzing trait differences from data of mixed aggregates.

\section{STATISTICS}

The stock- and sex-specific sea-age distributions (1-5 SW) of all nine salmon stocks were compared by using the $\chi^{2}$ test (SAS FREQ procedure) [60], but in some analyses only three sea-age categories (1SW; $2 \mathrm{SW} ; 3-5 \mathrm{SW})$ were used, because of small numbers of individuals in the older age classes. The mean sea age in the stocks was calculated separately for males and females. The differences in sea age between stocks were compared using the Kruskall-Wallis test (SAS NPAR1WAY procedure)[60].

The long-term changes in sex ratios and sea-age distributions between contemporary and historical data were analyzed by using the $\chi^{2}$ test and $t$-test.

Linear regression (SAS REG procedure) was used in analyzing the association between the mean male age (proportion of males) and female age, and between the mean male age and the sex ratio for each of the studied stocks.

Changes in the proportions of the older age classes as a function of time (years 2000-2009, a continuous variable) were analyzed for all the fish caught in Gulf of Bothnia (Fig. 1, subdivisions 30 and 31). As the number of older spawners was so low, the spawning age was analyzed as a binomial variable with the SAS GENMOD procedure [60], and differences between stocks were examined by using odds ratios (OR). For males, the sea age (response variable) was categorized into either $1 \mathrm{SW}$ (one sea-winter) or MSW (multi-sea-winter) (referred to here as model 1; SAS GENMOD), and for females either young (1-2 SW) or old (3-5 $\mathrm{SW}$ ) (referred to here as model 2; SAS GENMOD) in linear regression models [60].

\section{RESULTS}

\section{Spawning Age Differences Among Salmon Stocks}

The spawning-age distributions of the nine Atlantic salmon stocks differed significantly from each other both within and between the wild and reared groups, and especially between sexes (Fig. 2, Tables 4 and 5). In practice, males were regularly one year younger than females. Males were either one or two sea-years old and females two or three sea-years old. On average, about 70\% (68.7\%, 51.1$87.9 \%$ ) of the spawning males in all our contemporary salmon stocks were grilse, i.e. $1 \mathrm{SW}$ salmon, and only $5 \%$ of them matured in their third year or later in the sea (Table 4). For females, only less than 10\% (7.2\%, 2-17\%) matured at an age of 1 sea-year, and the large majority, about $80 \%(78.7 \%, 59-90 \%)$, matured as $2 \mathrm{SW}$ fish. On average, $14 \%$ of females spent more than two winters in the sea (Table 4).

Significant differences in spawning age distributions could be observed among both wild and sea-ranched stocks. Among the wild salmon stocks, the spawning-age distribution of males of the Swedish Byskeälven salmon differed statistically significantly $\left(\chi^{2}\right.$ test) from that of males of the other rivers (Tables $\mathbf{4}$ and $\mathbf{5}$ ). This stock had a clearly higher proportion $(15.5 \%)$ of old, $3 \mathrm{SW}$, male spawners than the other wild stocks, for which the average was only $6.7 \%$.

Among the wild females, the Vindelälven salmon had the oldest spawners, as over one-third of them were at least three sea-winters old (33\% were $3 \mathrm{SW}$ or older), and the female age distribution of this stock differed significantly $\left(\chi^{2}\right.$ test $)$ 


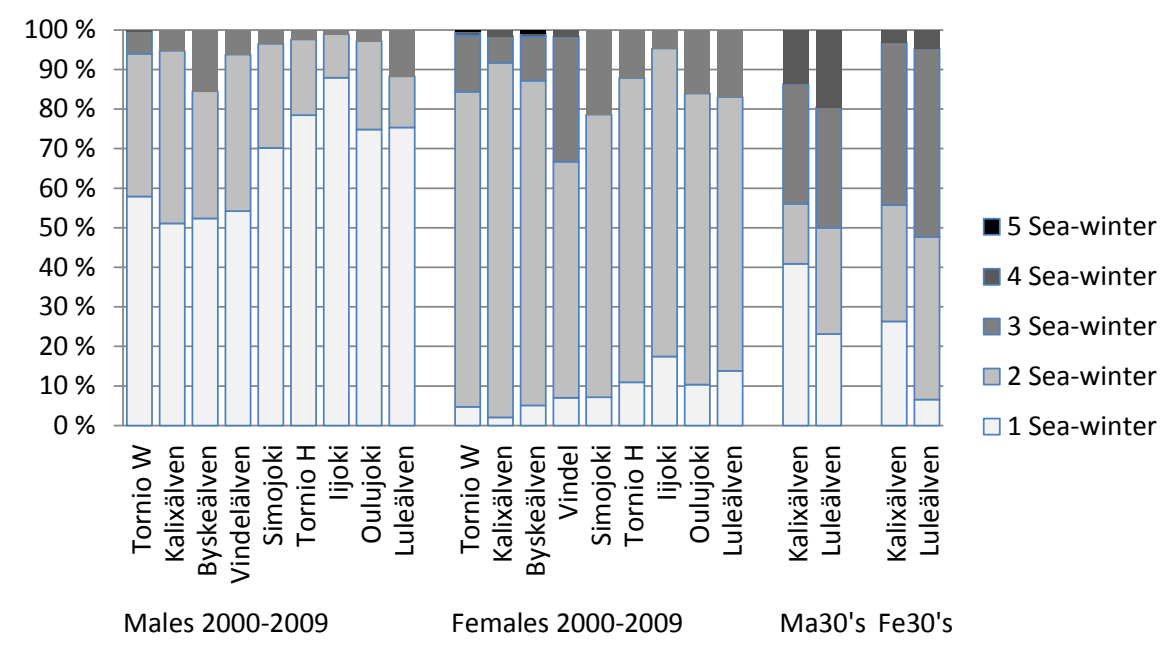

Fig. (2). Average spawning-age distribution in males and females of nine Atlantic salmon stocks in the Baltic Sea over the years 2000-2009 (wild stocks first) and also in the 1930s [40] in males (Ma30's) and females (Fe30's).

from that of the all other wild stocks, except the Simojoki salmon (Tables 4 and 5). The age distribution of Kalixälven female spawners differed in the opposite direction, as a clear majority $(89.6 \%)$ of Kalixälven female spawners were only 2 SW old.

Among the sea-ranched populations, male spawning ages differed in several cases, but the females were more similar in age. Although in all four sea-ranched hatchery stocks the proportion of male grilse was nearly $80 \%$ (79.8\%), the hatchery stocks nevertheless differed significantly from each other in pairwise comparisons, except for Oulujoki and Tornionjoki (Table 5). The female spawning-age distributions of the sea-ranched hatchery stocks were quite similar, and only the Iijoki stock with its youngest female spawners deviated statistically significantly from the other stocks (Tables 4 and 5). Among the Iijoki salmon, as many as $17.4 \%$ were female grilse, which are very rare in the wild. The two other sea-ranched salmon stocks mainly maintained as broodstocks, the Iijoki and Oulujoki stocks, also differed from each other, as older spawners were more common among the Oulujoki than the Iijoki salmon in both sexes (Tables $\mathbf{4}$ and $\mathbf{5}$ ).

The spawning-age differences between the wild and hatchery groups were large, especially for males. The mean spawning age for wild males was 1.5 sea-years and for searanched reared males 1.32 sea-years, while the corresponding ages for females were 2.12 sea-years and 2.00 sea-years (Table 4). In practice, all sea-ranched stocks differed highly significantly in relation to spawning-age distribution from all the other wild stocks, except from the Simojoki stock (Table 5). The Simojoki salmon stock, however, also partially has a hatchery history.

The oldest spawners were 5-SW-old females, and these were found in both the Byskeälven and wild Tornionjoki salmon stocks. The proportion of these old, 4-5 SW females was only $1 \%$ in all contemporary salmon stocks. The oldest male spawners (4 SW) originated from the wild Tornionjoki salmon stock.

The River Tornionjoki salmon stock currently has both a wild and a sea-ranched component. For both sexes, the mean spawning age was higher for the wild than the sea-ranched component (Table 4). The proportion of old, MSW males was twice as high in the wild Tornionjoki stock component $(42.1 \%, n=316)$ as in the sea-ranched component $(21.5 \%, n$ $=251$ ), although they shared the same genetic background and had been exposed to the same sea environment and offshore fishery. The mean male spawning age had changed from 1.48 to 1.23 sea-years. In females, the mean spawning age had changed from 2.13 sea-years to 2.01 sea-years (Table 4). The largest change in females was in the proportion of one-year-old spawners, as they composed about $4.7 \%$ in the wild component but $10.9 \%$ in the sea-ranched component. Old female spawners (4 SW and $5 \mathrm{SW}$ ) were only found in the wild component of the Tornionjoki salmon (Table 4; Fig. 2).

\section{Temporal Trends in Spawning Age and Sex Ratio}

When all males were divided into only two age classes according to their spawning age, either grilse, i.e. $1 \mathrm{SW}$ males $(n=786)$, or older, MSW males $(n=336)$, the mean spawning age differed highly significantly between the stocks (GENMOD; Type 3 test: $P<0.001$ ) [61]. There was also a slight indication of a decreasing trend in male spawning age over the ten-year period from 2000 to 2009 ( $P=$ 0.096) (Fig. 3a, model 1). In addition, the proportion of old (MSW) males was at least two times higher in the naturally reproducing Tornionjoki and Kalixälven stocks than in the sea-ranched stocks $(2.3<\mathrm{OR}<7.0)$. In the Iijoki searanched stock, the proportion of MSW males was less than half $(0.14<\mathrm{OR}<0.53)$ of that in all the other stocks (Table 6). The proportion of MSW fish was higher in all wild salmon stocks than in the reared stocks $(\mathrm{OR}>1$, Table 6; Fig. 3a).

When the females were divided into two spawning age classes, either younger $1-2 \mathrm{SW}(n=881)$ or older $3-5 \mathrm{SW}(n$ $=132$ ) spawners, the spawning age of females differed between salmon stocks $(P<0.01)$ but not between years (Fig. $3 \mathrm{~b}$; model 2), and no trend over time could thus be observed in the female spawning age of the contemporary stocks. The differences between sea-ranched and wild stocks were also smaller among females than males (Table 6), and the 
Table 4. Studied Atlantic salmon stocks, sample sizes, mean spawning age $(x)$ its standard error (S.E.) and spawning-age distribution of nine stocks in over 2000-2009 and also in two stocks (Kalixälven, Luleälven) in the 1930s [40], separately for females (F) and males (M). SW = sea winter $=$ sea age.

\begin{tabular}{|c|c|c|c|c|c|c|c|c|}
\hline Salmon stock & $\begin{array}{c}\text { Sample } \\
n\end{array}$ & \multicolumn{2}{|c|}{ Mean } & \multicolumn{5}{|c|}{ Spawning age (\%) } \\
\hline Tornionjoki W & 422 & 2.13 & 0.02 & 4.7 & 79.6 & 14.2 & 0.9 & 0.6 \\
\hline Kalixälven & 192 & 2.08 & 0.03 & 2.1 & 89.6 & 6.8 & 1.5 & \\
\hline Vindelälven & 57 & 2.28 & 0.08 & 7.0 & 59.6 & 31.6 & 1.8 & \\
\hline Simojoki & 42 & 2.14 & 0.08 & 7.1 & 71.5 & 21.4 & & \\
\hline All wild females & 830 & 2.12 & 0.02 & 4.4 & 80.5 & 13.6 & 1.1 & 0.4 \\
\hline Luleälven & 65 & 2.03 & 0.07 & 13.9 & 69.2 & 16.9 & & \\
\hline All reared females & 422 & 2.00 & 0.02 & 12.6 & 75.1 & 12.3 & & \\
\hline All females & 1252 & 2.08 & 0.01 & & 78.7 & 13.2 & 0.7 & 0.2 \\
\hline \multicolumn{9}{|c|}{ Males 2000s } \\
\hline Tornionjoki W & 316 & 1.48 & 0.03 & 57.9 & 36.1 & 5.7 & 0.3 & \\
\hline Kalixälven & 133 & 1.54 & 0.05 & 51.1 & 43.6 & 5.3 & & \\
\hline Byskeälven & 84 & 1.63 & 0.08 & 52.4 & 32.1 & 15.5 & & \\
\hline Oulujoki & 175 & 1.28 & 0.04 & 74.9 & 22.2 & 2.9 & & \\
\hline Luleälven & 77 & 1.36 & 0.08 & 75.3 & 13.0 & 11.7 & & \\
\hline All reared males & 693 & 1.32 & 0.02 & 79.8 & 17.0 & 3.2 & & \\
\hline All males & 1331 & 1.36 & 0.02 & 68.7 & 26.3 & 4.9 & 0.1 & \\
\hline \multicolumn{9}{|c|}{ Females 1930s } \\
\hline Kalixälven & 95 & 2.21 & 0.09 & 26.0 & 30.0 & 41.0 & 3.0 & \\
\hline Luleälven & 107 & 2.50 & 0.07 & 6.0 & 41.0 & 48.0 & 5.0 & \\
\hline \multicolumn{9}{|c|}{ Males 1930s } \\
\hline Kalixälven & 66 & 2.17 & 0.05 & 41.0 & 15.0 & 30.0 & 14 & \\
\hline Luleälven & 82 & 2.46 & 0.12 & 23.0 & 27.0 & 30.0 & 20 & \\
\hline All F 1930s & 202 & 2.27 & 0.06 & 15.8 & 35.6 & 44.6 & 4.0 & \\
\hline All M 1930s & 148 & 2.33 & 0.09 & 31.1 & 21.6 & 30.4 & 16.9 & \\
\hline
\end{tabular}


Table 5. Test results of the differences in spawning-age distributions $\left(\chi^{2}\right.$ test) of the nine Atlantic salmon stocks analyzed in this study. See spawning age distributions and sample sizes in Table 4. Test results for males are shown in the upper triangle and for females in the lower triangle.

\begin{tabular}{|c|c|c|c|c|c|c|c|c|c|}
\hline \multirow[b]{2}{*}{$\begin{array}{l}\text { Male } \\
\text { Female }\end{array}$} & \multicolumn{5}{|c|}{ Wild stocks } & \multicolumn{4}{|c|}{ Hatchery stocks } \\
\hline & 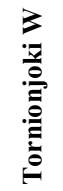 & 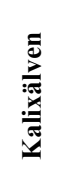 & 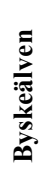 & 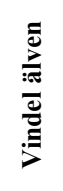 & $\frac{\text { 퐁 }}{\stackrel{\circ}{\circ}}$ & 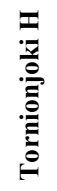 & $\stackrel{\square}{:}$ & $\frac{\frac{7}{\circ}}{\stackrel{\Xi}{\Xi}}$ & 竞 \\
\hline Kalixälven & $* *$ & & $*$ & ns & ns & $* * *$ & $* * *$ & $* * *$ & $* * *$ \\
\hline Byskeälven & ns & ns & & ns & $*$ & $* * *$ & $* * *$ & $* * *$ & $* *$ \\
\hline Vindelälven & $* *$ & $* * *$ & $* *$ & & ns & $* *$ & $* * *$ & * & $* *$ \\
\hline Simojoki & ns & $* *$ & $\mathrm{~ns}$ & ns & & $\mathrm{ns}$ & $* *$ & ns & $\mathrm{ns}$ \\
\hline Oulujoki & $\mathrm{ns}$ & $* * *$ & $\mathrm{~ns}$ & $*$ & ns & $\mathrm{ns}$ & $*$ & & $* *$ \\
\hline
\end{tabular}

$* * * P<0.001, * * P<0.01, * P<0.05$.
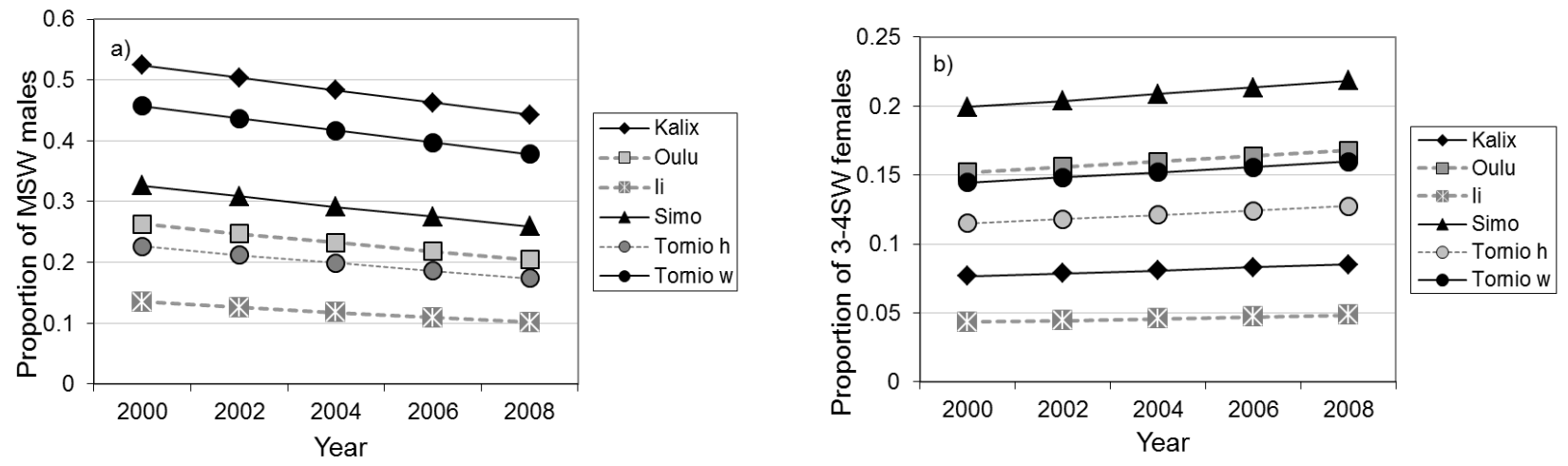

Fig. (3). The proportion of older spawners in the six Atlantic salmon spawning stocks over the years 2000-2009 in the Baltic Sea. The results for the proportion of spawning multi-sea-winter (MSW; 2-4 sea winters) males (a; model 1) and old females (3-4 sea winters) (b, model 2) are according to GENMOD models with the stock and year as predictors.

proportions of older females in wild stocks did not always surpass those in the hatchery stocks. The Kalixälven males were the oldest (49\% MSW; Tables 4 and 6), but females of the Kalixälven stock were quite young, and clearly younger than the females of the reared Oulujoki salmon and the Simojoki salmon $(\mathrm{OR}<1)$.

The historical spawning-age distributions for Kalixälven and Luleälven salmon stocks reported by Alm [40] clearly differed from the present data (2000-2009) for both sexes $\left(\chi^{2}\right.$ test: $\left.P<0.001\right)$ (Fig. 2; Table 4). Currently, spawners are younger.

The mean spawning age in the historical Luleälven wild stock was 2.5 sea-years for both females and males, and it is currently 2.03 sea-years for females and 1.36 sea-years for males in the sea-ranched Luleälven stock (Table 4). In the wild Kalixälven stock, the spawning age has also decreased since the $1930 \mathrm{~s}$, although the stock is still wild, so no changes could have resulted from hatchery rearing in this case. In the historical sample, the spawning age of both sexes was over two years, with the female spawning age being 2.21 sea-years and that of males 2.17 sea-years. In the contemporary data, the mean for females was 2.08 and for males 1.54 sea-years (Table 4). The spawning age of females had thus clearly decreased less than that of the males.

In the $1930 \mathrm{~s}$, nearly half (44\%) of Kalixälven male spawners were older, $3 \mathrm{SW}$ or $4 \mathrm{SW}$ old, but in the present data only $5 \%$ were $3 \mathrm{SW}$ old male spawners, as hyphenation has not been used elsewhere. For females, the 3 SW spawners previously formed the largest group, in both historical Kalixälven (41\%) and in the Luleälven (48\%) stocks, but at present their proportion is only $6.8 \%$ in Kalixälven and $16.9 \%$ in Luleälven. These differences between 
Table 6. Odds ratios (OR) (95\% CL in parentheses) for an older spawning age in different Atlantic salmon stock pairs. In all compared stocks, the male spawners of the first stocks were older than those of the second stock of the pair, and usually also in females but in two cases the order of the age distributions of the stocks were in females the opposite $\left({ }^{\circ}\right)(O R<1)$. The values are based on models 1 and 2 in Fig. (3).

\begin{tabular}{|l|c|c|}
\hline Stock pairs & Male, OR(CL) & Female, OR (CL) \\
\hline \hline Tornio W \& Tornio H & $2.9(1.9-4.2)^{* * *}$ & $3.7(1.3-10.6)^{*}$ \\
\hline Tornio W \& Ii & $5.4(3.3-8.8)^{* * *}$ & $\mathrm{~ns}$ \\
\hline Tornio W \& Oulu & $2.4(1.5-3.6)^{* * *}$ & $2.0(1.1-3.6)^{*}$ \\
\hline Tornio W \& Kalix & $\mathrm{ns}$ & $\mathrm{ns}$ \\
\hline Tornio H \& Ii & $1.9(1.1-3.2)^{*}$ & $\mathrm{~ns}$ \\
\hline Tornio H \& Kalix & $3.8(2.4-6.0)^{* * *}$ & $5.5(1.6-19.1)^{* *}$ \\
\hline Simo \& Ii & $3.1(1.5-6.3)^{* *}$ & $0.33(0.14-0.81)^{*}$ \\
\hline Kalix \& Simo & $2.3(1.2-4.4)^{*}$ & $4.0(1.3-12.3)^{*}$ \\
\hline Oulu \& Ii & $2.3(1.3-3.9)^{* *}$ & $\mathrm{~ns}$ \\
\hline Kalix \& Ii & $7.0(4.1-12.2)^{* * *}$ & $3.1(1.9-5.1)^{* * *}$ \\
\hline Kalix \& Oulu & & \\
\hline
\end{tabular}

$* * * P<0.001, * * P<0.01, * P<0.05, \mathrm{~ns}=$ nonsignificant.

historical and contemporary spawning age distributions in Kalixälven and Luleälven stocks were highly significant for both males (Kalix: $\chi^{2}$ test, $\chi^{2}=49.9$, df $=3: P<0.001$; Lule: $\left.\chi^{2}=47.7, \mathrm{df}=3: P<0.001\right)$ and females (Kalix: $\chi^{2}=111.8$, $\mathrm{df}=3: P<0.0015$; Lule: $\left.\chi^{2}=23.0, \mathrm{df}=3: P<0.001\right)$.

For both sexes, the change towards younger spawners was larger in the sea-ranched Luleälven stock than in the wild Kalixälven stock in the comparison with the historical data. In the 1930s, the mean male spawning age of the wild Kalixälven (mean age 2.17) and Luleälven (2.46) salmon did not differ (Kruskall-Wallis test: $\chi^{2}=2.7 \mathrm{df}=1: P=\mathrm{ns}$ ), but males of the Luleälven hatchery stock are now younger (1.36) than Kalixälven wild males (1.54) $\left(\mathrm{K}-\mathrm{W}: \chi^{2}=7.6\right.$, df $=1: P<0.01)$ (Fig. 2; Table 4). In the 1930s, wild Luleälven females were older (mean 2.50) than wild Kalixälven females (2.21) (K-W: $P<0.05$ and distribution: $\chi^{2}=15.1$, $\mathrm{df}=$ 3: $P<0.01)$, but the mean spawning age is now approximately the same in both stocks (Luleälven 2.03; Kalixälven 2.08) $(\mathrm{K}-\mathrm{W}: P=\mathrm{ns})$ and the distributions differ $\left(\chi^{2}=22.0, \mathrm{df}\right.$ $=3 ; P<0.001)$. Hatchery rearing has reduced the spawning age of both sexes in the Luleälven stock (K-W: $P<0.001)$.

The difference in spawning age between sexes also increased from the 1930s to the 2000s. In 1930s, the spawning age of females (mean: 2.21) and males (2.17) in the wild Kalixälven stock did not differ (Kruskall-Wallis test: $P=\mathrm{ns}$ ), but in the 2000s, males were younger (1.54) than females (2.08) (K-W: $P<0.001)$. Similarly, in the 1930s, the spawning age of females (mean: 2.50) and males (2.46) in the Luleälven stock was similar (Kruskall-Wallis test: $P=\mathrm{ns}$ ), but in the 2000s, spawning males were younger (1.36) than females (2.03) (K-W: $P<0.001)$. In the 1930 s, old males and females were equally common (approximately half of males 3-4 SW), but old females (8-17\% 3-4 SW) are currently more common than old males $(5-12 \% 3-4 \mathrm{SW})$ in these stocks (1930s Kalixälven, male $\&$ female, $\chi^{2}$ test: $\chi^{2}=$ 12.9, df $=3: P<0.01$; present Kalixälven, male \& female: $\chi^{2}$ $=111.1, \mathrm{df}=3: P<0.001)$.

The sex ratio (males/females) for the wild Kalixälven salmon spawners in the 2000 s and 1930 s was the same $(0.41$; $\left.\chi^{2}=0.0, \mathrm{df}=1: P=\mathrm{ns}\right)$, but for the Luleälven salmon stock the sex ratio has changed from female dominance to a slight male dominance, when changing from wild to hatchery production, as the proportion of males has increased from 0.43 to 0.54 over time $\left(\chi^{2}=3.8, \mathrm{df}=1: P=0.051\right)$ (Fig. 4a).

The sex ratios of salmon stocks varied markedly from 0.41 (female dominance) in the wild Kalixälven stock to 0.69 (male dominance) in the Iijoki hatchery stock (Fig. 4a). The mean sex ratio for the five wild stocks was 0.46 , and for the four reared stocks as high as 0.61 (Table 3). The male spawning age was also lowest in those populations that had a male-biased sex ratio (male spawning age $=2.20$ 1.54 * proportion of males, $F=106.9_{(1,7)}, P<0.001$; years 2000-2009) (Fig. 4a). Thus, if males were abundant, they were also young. The male and female spawning ages of the same stocks also usually correlated (male sea-age $=1.02$ $0.74 *$ female sea-age, $\left.F=6.5_{(1,7)}, P<0.05\right)$ (Fig. 4b).

\section{DISCUSSION}

The number of genetically differentiated salmon stocks has changed dramatically in the Baltic Sea $[12,15,61]$ since the 1930s. Besides the loss of stocks, ascending salmon are now younger, there is less variation in the spawning age, and the hatchery-reared spawning stocks have become maledominated when compared to historical native stocks of the same river. An ongoing slight decrease in the male spawning age was even observed after 2000. The spawning age structure of wild and sea-ranched stocks as groups differed and also the hatchery and wild components of the same river 


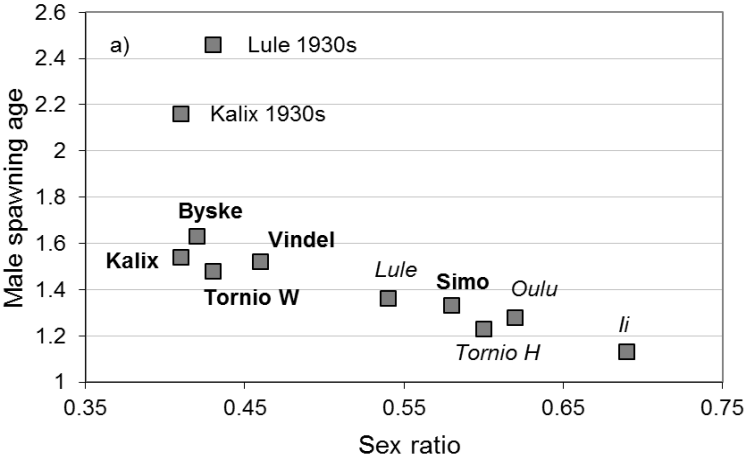

(a)

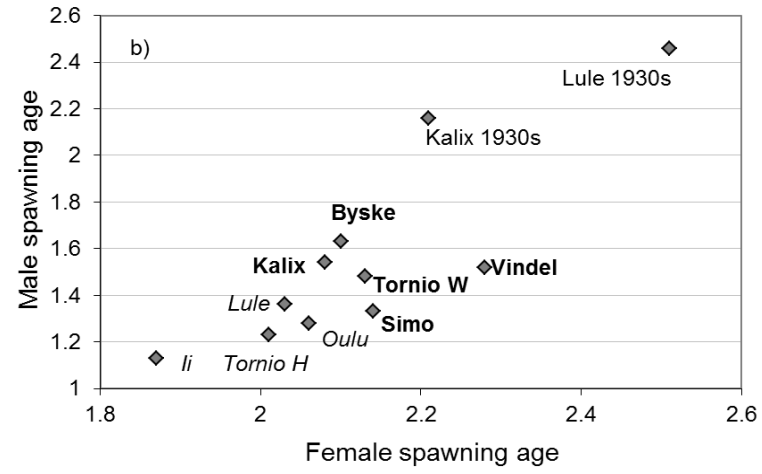

(b)

Fig. (4). Stock-specific male spawning age in relation to the sex ratio (proportion of males) (a) and in relation to female spawning age (b) in nine Atlantic salmon stocks in 2000-2009 and in two stocks in the 1930s [40] in the Baltic Sea. The contemporary wild stocks are indicated with bold text on the figure.

stock, Tornionjoki, differed significantly. These long- and short-term changes are likely to be responses to the changing natural environment, fishery selection, hatchery rearing, and a combination of these factors.

\section{Spawning Age Variation Caused by the Natural Envi- ronment}

Differences in the spawning age among river stocks are likely to represent adaptation to environmental conditions, such as the latitude and size of the home river [4, 7, 40]. For example, along the Norwegian coast, the proportion of grilse (1 SW fish) is higher in northern rivers [7]. Furthermore, northern stocks are known to have more freshwater years than southern stocks, and Alm [40] observed a correlation between early maturation and a high number of freshwater years. In the present study, the female spawning age of wild stocks decreased northwards along the Swedish coast from Vindelälven (2.28) to Byskeälven (2.10) and Kalixälven (2.08). The large variation in the sea-age distribution of the Tornionjoki salmon stock is partly explained by the size of the river, as the upstream migration distance may be over $500 \mathrm{~km}[12]$.

The proportion of old male spawners and the spawning age have decreased synchronously over time. Factors common to all stocks during the feeding migration include changes in the sea environment, such as the sea surface temperature, conditions in the feeding area, such as the availability of food, and the offshore and coastal fishery. This reasoning has proved correct in several previous studies related to salmon abundance, growth, and migration distance, in which synchronous trends have been related to common environmental factors $[6,13,62,63]$. The decrease in the proportion of old males has also been observed previous studies, as Järvi [64] reported approximately $11 \%$ of the spawners to be 4-6 SW salmon in the 1930s and 1940s, but an analysis sixty years later reported only $0.5-2 \%$ of salmon of that age [15].

The sea temperature of the Baltic Sea is known to have increased in recent decades [65]. This may have promoted faster salmon growth, both directly and also indirectly via increased food availability [33], causing a decrease in the average spawning age. The increase in the sea surface temperature in the Baltic Sea has previously been associated with an increase in the length of 2 SW Simojoki, Iijoki, Tornionjoki and Oulujoki salmon captured from 1972-1995 during the spawning migration [33]. According to Jonsson et al. [66], both high food quality and a high sea temperature increase the growth of salmon and the probability of early maturation.

Life-history traits are often correlated [67], and changes in growth rate tend to affect the spawning age [68-70]. Good growth conditions for post-smolts reduce the spawning age in Baltic salmon [68], assumedly because fish reach a threshold size for maturation at an earlier age. The same factor probably explains the observation that good late summer growth in North Atlantic salmon stocks [71] was associated with an increased proportion of $1 \mathrm{SW}$ spawners.

\section{The Fishery as a Selective Force}

For decades, the Baltic salmon has been a target of the selective offshore drift-net fishery, which only ended in 2008. Even today, after reaching the legal minimum size, salmon become the target of efficient long-line and trap-net fishing, and the spawners thus represent the survivors remaining from the offshore and coastal fishery. In the 1930s, there was no offshore fishery, and the age structure of spawners directly represented the genetic composition of the stock. This difference alone may explain a large part of the observed differences between salmon stocks of the same rivers in the 1930 s and the 2000s. It does not, however, explain the differences also detected between salmon stocks within the contemporary data and within the data from the 1930s. Furthermore, differences between wild and searanched groups within the contemporary data cannot be explained by differences in the fishery, as they are currently equally targeted.

Besides changing the age structure of spawners, fishery selection is likely to have evolutionary effects on the size and spawning age of the next generation. For decades, the fishery has targeted the fastest-growing fish [29], and more importantly early-maturing fish are exposed to the fishery in the Baltic Main for a clearly shorter time period when compared to the late-maturing fish, which are much more likely to be caught before maturation. Intensive fishing may also affect the sex ratio [37], as small males, maturing at one year 
old and even at a length of less than $60 \mathrm{~cm}$, are more likely to escape the fishery than females maturing only a year later. Life-history theory $[72,73]$ gives predictions for the optimal age of semelparous reproduction under different conditions. Particularly in a risky and uncertain environment, the best strategy is to reproduce early.

As the breeding success of male salmon is not as closely dependent on size as that of female salmon, the sexes have different spawning age optima [17]. Female fecundity, expressed as the number and size of the eggs, is closely linked to body size [17]. In addition, there may be a physiological size or age threshold for female maturation, which would explain the normally very low percentage of $1 \mathrm{SW}$ female spawners. However, in the Iijoki hatchery stock with successive brood stock generations, even the number of these rare $1 \mathrm{SW}$ female spawners has increased [44].

Thus, the present phenotypic age distribution and the difference between sexes are likely to reflect the consequences of fishery selection. Fishing can also cause detectable evolutionary responses, even within some generations [29, 74, 75]. As this intensive sea fishery has lasted for several generations and the age at maturity of salmon is known to be highly heritable $\left(\mathrm{h}^{2}=0.48\right)$ [76], we may have witnessed a response to the selective fishery, although it has been difficult to show [33].

\section{The Effect of Hatchery Rearing on the Spawning Age}

In addition to factors related to the common sea environment, hatchery rearing as such tends to reduce the spawning age of the more domesticated stocks, as wild salmon reproduce later. Better food quality and consequently increased growth in the hatchery environment may cause this difference. Previous studies have shown that hatchery-reared smolts are regularly younger but larger (Simojoki salmon: 2year-olds, $18.6 \mathrm{~cm})$ than wild smolts $(2-4$-year-olds: 15.5 $\mathrm{cm})$ [26], which indicates that hatchery offspring have a good growth start.

The sea-ranched spawners of the Tornionjoki salmon were significantly younger than the wild spawners of the same river, despite having the same genetic origin, and exposure to the same sea environment and fishery during migration. This leaves the selection of hatchery spawners, and selective effects of the hatchery environment as candidates for the difference. Among the contemporary stocks, the Iijoki stock, with the longest history of hatchery generations [44], has the youngest spawners and least variation in spawning age. Furthermore, according to Vainikka et al. [33], during 1972-1995, the average proportion of grilse was already higher in hatchery stocks than in the wild stocks. Similarly, several other studies $[16,77]$ have reported a decrease in the spawning age due to hatchery rearing.

Hatchery rearing does not alone explain the changes in the spawning age structure, as the spawning age of the wild Kalixälven stock has also changed, although it is still wild. Nevertheless, when compared to historical data, the spawning age of both sexes had decreased more for the sea-ranched Luleälven stock than for the wild Kalixälven stock, supporting the view of the influence of hatchery rearing as a factor decreasing spawning age.
An increased growth rate is the probable factor behind the tendency of reared salmon to mature at a younger age. Rearing is also known to genetically select for faster growth [21]. Moreover, the growth rate and age at maturity of salmon have a negative correlation $(\mathrm{R}=-0.52)$ [8], and the heritability of growth $\left(\mathrm{h}^{2}=0.3\right)$ and age at maturity $\left(\mathrm{h}^{2}=\right.$ $0.48)$ is relatively high $[76,78]$. Thus, we assume that in addition to the favorable hatchery environment, selection for increased growth both in hatcheries and in the wild has reduced the age at maturity in the hatchery stocks [33].

There was a clear difference in the sex ratio between the wild (mean 0.46) and released, sea-ranched salmon stocks (mean 0.61) in our data (Table 3). Females were overrepresented in the wild stocks, but males in the hatchery-reared salmon stocks. The effect of rearing on the sex ratio was also clear when the contemporary and historical stocks were compared. Females formed the majority in both the historical Luleälven stock and Kalixalven stocks, but in the contemporary Luleälven hatchery stock the majority of spawners were males, while females formed the majority in the still wild Kalixälven stock. The early-maturating male parr remain in the wild rivers as precocious males, but in hatchery stocks all immature and precociously mature fish are released [79]. As the survival of these precocious males in the sea is lower than that of immature smolts $[79,80]$, the effects of this on the final sex ratio of the spawners remain open. Small, undersized (below $60 \mathrm{~cm}$ ) males may also escape the fishery more efficiently than females.

Genetic variation allows adaptation to new environmental conditions, but variation also creates a buffer against local extinction, or extirpation, due to environmental variation over the long term. Spawning-age variation reduces the probability of all individuals in a cohort suffering as a consequence of the same temporary environmental conditions $[81,82]$. The population growth rate and life-history variation appear to be positively correlated in the long term, even though they may be inversely connected over short time periods [81].

\section{CONCLUSION}

Our study demonstrated that the Baltic Sea salmon stocks have had and still have adaptive stock-specific variation in their spawning age. The variation in spawning age is now more narrow, especially among males and in hatchery stocks, and all spawners are younger compared to the 1930s. Faster growth and earlier maturation are responses to simultaneous selection for rising seawater temperatures, better nutrition, hatchery rearing, and fishery selection. Some aspects of hatchery domestication, fishery selection, and fishing regulation act in different ways in males and females, causing male-biased sex ratios and the production of very young hatchery-reared males.

\section{CONFLICT OF INTEREST}

The authors confirm that this article content has no conflict of interest.

\section{ACKNOWLEDGEMENTS}

The data from 2006 onwards used in this study were collected as part of an EU sampling program, the National Data 
Collection Programme under Council Regulation (EC) $\mathrm{N}^{\circ}$ 199/2008. The work before this, from 2000-2005, was financed by the Finnish Game and Fisheries Research Institute and the Finnish Ministry of Agriculture and Forestry. EU financing covered scale collection, age determination, and preliminary DNA analysis of the data, as reported annually in the ICES WGBAST reports. The age determination of the fish was performed at the responsible institutes for Finland and Sweden: the Finnish Game and Fisheries Research Institute and the Swedish Institute of Freshwater Research, and later at the Swedish University of Agricultural Sciences. Swedish colleagues are acknowledged for the permission to use the Swedish catch samples from the Bothnian Bay from 2006 to 2009. Dr Roy Siddall revised the English language.

\section{REFERENCES}

[1] Garcia de Léaniz C, Fleming IA, Einum S. et al. A critical review of adaptive genetic variation in Atlantic salmon: implications for conservation. Biol Rev 2007; 82: 173-211.

[2] Hansen LP, Jonsson B, Andersen R. Salmon ranching experiments in the River Imsa: is homing dependent on sequential imprinting of the smolts? In: Brannon E, Jonsson B., Eds. Proc. Salmonid Migration and Distribution Symp.: School of Fisheries, University of Washington, Seattle, WA/ Norwegian Institute for Nature Research, Trondheim, Norway 1989: pp. 19-29.

[3] Hansen LP, Jonsson B. Homing of Atlantic salmon: effects of juvenile learning on transplanted post-spawners. Anim Behav 1994; 47: 230-22.

[4] Schaffer WM, Elson PF. The adaptive significance of variations in life history among populations of Atlantic salmon in North America. Ecology 1975; 56: 577-90.

[5] Jonsson N, Hansen LP, Jonsson B. Variation in age, size and repeat spawning of adult Atlantic salmon in relation to river discharge. $\mathrm{J}$ Anim Ecol 1991; 60: 937-47.

[6] Kallio-Nyberg I, Peltonen H, Rita H. Effects of stock-specific and environmental factors on the feeding migration of Atlantic salmon (Salmo salar) in the Baltic Sea. Can J Fish Aquat Sci 1999; 56: 853-61.

[7] L'Abée-Lund JH, Vøllestad LA, Beldring S. Spatial and temporal variation in the grilse proportion of Atlantic salmon in Norwegian rivers. Trans Am Fish Soc 2004; 133: 743-61.

[8] Gjerdem T. Genetic variation in age at maturity and its relation to growth rate. In: Iwamoto RN, Sower S, Eds. Salmonid reproduction. Washington Sea Grant Program. University of Washington, Seattle, WA 1985; pp. 52-61.

[9] Scarnecchia DL, Ísaksson Á, White SE. Effects of oceanic variations and west Greenland fishery on age at maturity of Icelandic west coast stocks of Atlantic salmon (Salmo salar). Can J Fish Aquat Sci 1989; 46(1): 16-27.

[10] Jonsson N, Jonsson B. Size and age of maturity of Atlantic salmon correlate with the North Atlantic Oscillation Index (NAOI). J Fish Biol 2004; 64: 241-7.

[11] Scarnecchia DL. Age at sexual maturity in Icelandic stocks of Atlantic salmon (Salmo salar). Can J Fish Aquat Sci 1983; 40: 1456-68.

[12] Romakkaniemi A, Perä I, Karlsson L, Jutila E, Carlsson O, Pakarinen T. Development of wild Atlantic salmon stocks in the rivers of the northern Baltic Sea in response to management measures. ICES J Mar Sci 2003; 60: 329-42.

[13] Niemelä E, Erkinaro J, Dempson JB, et al. Temporal synchrony and variation in abundance of Atlantic salmon (Salmo salar) in two subarctic Barents Sea rivers: influence of oceanic conditions. Can J Fish Aquat Sci 2004; 61: 2384-91.

[14] Niemelä E, Orell P, Erkinaro J, et al. Previously spawned Atlantic salmon ascend a large subarctic river earlier than their maiden counterparts. J Fish Biol 2006; 69: 1151-63.

[15] Jokikokko E, Jutila E. Effect of fishing regulation on the occurrence of repeat spawners and age distribution of Atlantic salmon in a northern Baltic river. Fish Manag Ecol 2005; 12: 341-7.

[16] Kallio-Nyberg I, Koljonen ML. The genetic consequence of hatchery-rearing on life-history traits of the Atlantic salmon (Salmo salar $\mathrm{L}$.): a comparative analysis of sea- ranched salmon with wild and reared parents. Aquaculture 1997; 153: 207-24.

[17] Fleming IA. Pattern and variability in the breeding system of Atlantic salmon (Salmo salar), with comparisons to other salmonids. Can J Fish Aquat Sci 1998; 55 (Suppl. 1): 59-76.

[18] Hutchings JA. The cod that got away. Nature 2004; 428: 899-900.

[19] Olsen EM, Lilly GR, Heino M, Morgan J, Brattey J, Dieckmann U. Assessing changes in age and size at maturation in collapsing populations of Atlantic cod (Gadus morhua). Can J Fish Aquat Sci 2005; 62: 811-23.

[20] Araki H, Berejikian BA, Ford MJ, Blouin MS. Fitness of hatcheryreared salmonids in the wild. Evol Appl 2008; 1(2): 342-55.

[21] Fleming IA, Agustsson T, Finstad B, Johnsson JI, Björnsson BT. Effects of domestication on growth physiology and endocrinology of Atlantic salmon (Salmo salar). Can J Fish Aquat Sci 2002; 59 (8): 1323-30.

[22] Hindar K, Fleming IA, McGinnity P, Diserud O. Genetic and ecological effects of salmon farming on wild salmon: modelling from experimental results. ICES J Mar Sci 2006; 63: 1234-47. doi: 10.1016/j.icesjms.2006.04.025

[23] McGinnity P, Prodöhl P, Ferguson A, et al. Fitness reduction and potential extinction of wild populations of Atlantic salmon, Salmo salar, as a result of interactions with escaped farm salmon. Proc $\mathrm{R}$ Soc Lond B 2003; 270: 2443-50.

[24] Fraser DJ, Minto C, Calver AM, Eddington JD, Hutchings JA. Potential for domesticated-wild interbreeding to induce maladaptive phenology across multiple populations of wild Atlantic salmon (Salmo salar). Can J Fish Aquat Sci 2010; 67(11): 1768-75.

[25] Jutila E, Jokikokko E, Kallio-Nyberg I, Saloniemi I, Pasanen P. Differences in sea migration between wild and reared Atlantic salmon (Salmo salar) in the Baltic Sea. Fish Res 2003; 60: 333-43.

[26] Kallio-Nyberg I, Saloniemi I, Jutila E, Jokikokko E. Effect of hatchery rearing and environmental factors on the survival, growth and migration of Atlantic salmon in the Baltic Sea. Fish Res 2011; 109: 285-94.

[27] Consuegra S, Garcia de Léaniz C, Serdio A, Verspoor E. Selective exploitation of early running fish may induce genetic and phenotypic changes in Atlantic salmon. J Fish Biol 2005; 67 (Suppl A): 129-45.

[28] Quinn TP, McGinnity P, Gross TF. Long-term declines in body and shifts in run timing of Atlantic salmon in Ireland. J Fish Biol 2006 68: $1713-30$

[29] Jörgensen C, Enberg K, Dunlop ES, et al. Ecology: managing evolving fish stocks. Science 2007; 318: 1247-8.

[30] Cuende FX, Prouzet P. Comparison of Atlantic salmon, Salmo salar $\mathrm{L}$., stocks exploited by commercial fisheries in the Adour Basin, France at end of the $19^{\text {th }}$ and $20^{\text {th }}$ centuries. Aquacult Res 1992; 23(3): 373-83.

[31] Brana F, Garrido R, Nicieza AG. Historical changes in age structure of Atlantic salmon, Salmo salar L., in the River Eo, northern Spain. Fish Manag Ecol 1995; 2(4): 279-87.

[32] Welton JS, Beaumont RC, Ladle M. Timing of migration and changes in age structure of Atlantic salmon, Salmo salar L., in the River Frome, a Dorset chalk stream, over a 24-year period. Fish Manag Ecol 1999; 6: 437-58.

[33] Vainikka A, Kallio-Nyberg I, Heino M, Koljonen ML. Divergent trends in life-history traits between Atlantic salmon Salmo salar of wild and hatchery origin in the Baltic Sea. J Fish Biol 2010; 76: $622-40$.

[34] Koljonen ML. Annual changes in the proportions of wild and hatchery Atlantic salmon (Salmo salar) caught in the Baltic Sea ICES J Mar Sci 2006; 63: 1274-85.

[35] Jutila E, Pruuki V. The enhancement of the salmon stocks in the Simojoki and Tornionjoki rivers by stocking parr in the rapids. Aqua Fennica 1988; 18: 93-99.

[36] Jutila E, Jokikokko E, Julkunen M. Management of Atlantic salmon in the Simojoki river, northern Gulf of Bothnia: effects of stocking and fishing regulation. Fish Res 2003; 64: 5-17.

[37] ICES. Report of Baltic Salmon and Trout Assessment Working Group (WGBAST), 22-30 March 2011, Riga, Latvia. ICES CM 2011/ACOM:08. 297 pp.

[38] Michielsens CGJ, McAllister MK, Kuikka S, et al. A Bayesian state-space mark-recapture model to estimate exploitation rates in mixed-stock fisheries. Can J Fish Aquat Sci 2006; 63: 321-34.

[39] Kallio-Nyberg I, Jutila E, Jokikokko E, Saloniemi I. Survival of reared Atlantic salmon and sea trout in relation to marine conditions of smolt year in the Baltic Sea. Fish Res 2006; 80: 295-304. 
[40] Alm G. Salmon in the Baltic Precincts. Rapp P v Réun Cons Int Explor Mer 1934; XCII: 1-63

[41] Haikonen A, Romakkaniemi A, Ankkuriniemi M, Keinänen M, Pulkkinen K, Vihtakari M. Monitoring of the salmon and trout stocks in the River Tornionjoki in 2005. Finnish Game and Fisheries Research Institute. Kala- ja riistaraportteja 2006; 379: 53 pp. + 3 appendices. (In Finnish and English.)

[42] Makkonen J, Westman K, Pursiainen M, et al. Viljelykantarekisteri. (Hatchery stock register). Finnish Game and Fisheries Research Institute. Kala- ja riistaraportteja 2000; 200. 48: (In Finnish.)

[43] Kallio I. Vaelluskalojen nykyinen tila ja hoito. Riista- ja kalatalouden tutkimuslaitos. Monistettuja julkaisuja 1986; 44: 1-51. (In Finnish.)

[44] Säisä M, Koljonen ML, Tähtinen J. Genetic changes in Atlantic salmon stocks since historical times and the effective population size of a long-term captive breeding programme. Conserv Genet 2003; 4: 613-27.

[45] Koljonen ML. Electrophoretically detectable genetic variation in natural and hatchery stocks of Atlantic salmon in Finland. Hereditas 1989; 110: 23-35.

[46] Laikre L, Palmé A, Josefsson M, Utter F, Ryman N. Release of Alien Populations in Sweden. AMBIO 2006; 35: 255-61.

[47] Koljonen ML, Pella JJ. The advantage of using smolt age with allozymes for assessing wild stock contributions to Atlantic salmon catches in the Baltic Sea. ICES J Mar Sci 1997; 54: 1015-30.

[48] McConnell SK, O'Reilly P, Hamilton L, Wright JN, Bentzen P. Polymorphic microsatellite loci from Atlantic salmon (Salmo salar) - genetic differentation of North American and European populations. Can J Fish Aquat Sci 1995; 52: 1863-72.

[49] O'Reilly PT, Hamilton LC, McConnell SK, Wright JM. Rapid analysis of genetic variation in Atlantic salmon (Salmo salar) by PCR multiplexing of dinucleotide and tetranucleotide microsatellites. Can J Fish Aquat Sci 1996; 53: 2292-8.

[50] Cairney M, Taggart JB, Hoyheim B. Characterization of microsatellite and minisatellite loci in Atlantic salmon (Salmo salar L.) and cross-species amplification in other salmonids. Mol Ecol 2000; 9: 2175-8.

[51] King TL, Eackles MS, Letcher BH. Microsatellite DNA markers for the study of Atlantic salmon (Salmo salar) kinship, population structure, and mixed-fishery analyses. Mol Ecol Notes 2005; 5:1302 .

[52] Slettan A, Olsaker I, Lie Ø. Polymorphic Atlantic salmon, Salmo salar L., microsatellites at the SSOSL438, SSOSL439 and SSOSL444 loci. Anim Genet 1996; 26: 277-85.

[53] Paterson S, Piertney SB, Knox D, Gilbey J, Verspoor E. Characterization and PCR multiplexing of novel highly variable tetranucleotide Atlantic salmon (Salmo salar L.) microsatellites. Mol Ecol Notes 2004; 4: 160-2.

[54] Säisä M, Koljonen ML, Gross R, et al. Population genetic structure and postglacial colonization of Atlantic salmon (Salmo salar) in the Baltic Sea area based on microsatellite DNA variation. Can J Fish Aquat Sci 2005; 62(8): 1887-904.

[55] Vuori K, Kiljunen M, Kanerva M, Koljonen ML, Nikinmaa M. Stock-specific variation in food webs, diet and environmental stress markers in Atlantic salmon Salmo salar during feeding migration in the Baltic Sea. J Fish Biol 2012; 81: 1815-33.

[56] Pella JJ, Masuda M. Bayesian methods for analysis of stock mixtures from genetic characters. Fish Bull 2001; 99: 151-67

[57] Gelman A, Rubin DB. Inference from iterative simulation using multiple sequences. Stat Sci 1992; 7: 457-511.

[58] Palm S, Dannewitz J, Järvi T, Koljonen ML, Prestegaard T, Olsén, H. No indications of Atlantic salmon (Salmo salar) shoaling with kin in the Baltic Sea (Salmo salar, L.). Can J Fish Aquat Sci 2008; 65: 1738-48.

[59] Moran P, Bromaghin JF, Masuda M. Use of genetic data to infer population-specific ecological and phenotypic traits from mixed aggregations. PLoS ONE 2014; 9 (6): e98470. doi:10.1371/journal.pone.0098470

[60] SAS Institute. SAS OnlineDoc ${ }^{\circledR}$ Versio 9.3. SAS Institute Inc., Cary, NC, USA 2012.

[61] Eriksson T, Eriksson LO. The status of wild and hatchery propagated Swedish salmon stocks after 40 years of hatchery releases in the Baltic rivers. Fish Res 1993; 18: 147-59.

[62] Friedland KD, Reddin DG, Kocik JF. Marine survival of North American and European Atlantic salmon: effects of growth and environment. ICES J Mar Sci 1993; 50: 481-92.

[63] Jensen AJ, Fiske P, Hansen LP, Johnsen BO, Mork KA, Naesje TF. Synchrony in marine growth among Atlantic salmon (Salmo salar) populations. Can J Fish Aquat Sci 2011; 68: 444-57.

[64] Järvi TH. On the periodicity of salmon reproduction in the northern Baltic Sea and its causes. Rapp P v Réun Cons Int Explor Mer 1948; 119: $131 \mathrm{pp}$.

[65] Mackenzie BR, Gislon H, Möllmann C, Köster FW. Impact of 21st century climate change on the Baltic Sea fish community and fisheries. Glob Change Biol 2007; 13: 1348-67.

[66] Jonsson B, Jonsson N, Finstad G. Effects of temperature and food quality on age and size maturity in ectotherms: and experimental test with Atlantic salmon. J Anim Ecol 2013; 82(1): 201-10 Doi: $10.1111 / \mathrm{j} .1365-2656.2012 .02022 \mathrm{x}$

[67] Hutchings JA, Jones MEB. Life history variation and growth rate thresholds for maturity in Atlantic salmon, Salmo salar. Can J Fish Aquat Sci 1998; 55 (Supp. 1): 22-47.

[68] Salminen M. Relationships between smolt size, postsmolt growth and sea age at maturity in Atlantic salmon ranched in the Baltic Sea J Appl Ichthyol 1997; 13: 121-30.

[69] Jonsson N, Jonsson B, Hansen LP. The marine survival and growth of wild hatchery-reared Atlantic salmon. J Appl Ecol 2003; 40: 900-11.

[70] Otero J, Jensen AJ, L'Abée-Lund JH, Stenseth NC, Storvik GO, Vøllestad LA. Contemporary ocean warming and freshwater conditions are related to later sea age at maturity in Atlantic salmon spawning in Norwegian rivers. Ecol Evol 2012; 2(9): 2192-203.

[71] Friedland KD, Haas RE. Marine post-smolt growth and age at maturity of Atlantic salmon. J Fish Biol 1996; 48: 1-15.

[72] Winemiller KO, Rose KA. Patterns of life-history diversification in North American fishes: implications for population regulation. Can J Fish Aquat Sci 1992; 49: 2196-218.

[73] Heino M, Kaitala V. Evolution of resources allocation between growth and reproduction in animals with indeterminate growth. J Evol Biol 1999; 12: 423-9. doi: 10.1046/j.1420-9101.1999.00044.x

[74] Heino M, Godo OR. Fisheries-induced selection pressures in the context of sustainable fisheries. Bull Mar Sci 2002; 70: 639-56.

[75] Hard JJ, Gross MR, Heino M, et al. Evolutionary consequences of fishing and their implications for salmon. Evol Appl 2008; 1: 388408. doi:10.1111/j.1752-4571.2008.00020.x

[76] Gjerde B. Response to individual selection for age at sexual maturity in Atlantic salmon. Aquaculture 1984; 38: 229-40.

[77] Kostow KE. Differences in juvenile phenotypes and survival between hatchery stocks and a natural population provide evidence for modified selection due to captive breeding. Can J Fish Aquat Sci 2004; 61: 577-89.

[78] Kinghorn BP. A review of quantitative genetics in fish breeding. Aquaculture 1983; 31: 283-304.

[79] Lundqvist H, Clarke WC, Johnsson H. The influence of precocious sexual maturation on survival to adulthood of river stocked Baltic salmon, Salmo salar, smolts. Holarct Ecol 1988; 11: 60-9.

[80] Kallio-Nyberg I, Salminen M, Saloniemi I, Kannala-Fisk L. Marine survival of reared Atlantic salmon in the Baltic Sea: The effect of smolt traits and annual factors. Fish Res 2009; 96: 289-95.

[81] Greene CM, Hall JE, Guilbault KR, Quinn TP. Improved viability of populations with diverse life-history portfolios. Biol Lett 2010; 6: 382-6.

[82] Schindler DE, Hilborn R, Chasco B, et al. Population diversity and portfolio effect in and exploited species. Nature 2010; 464: 609-12.

Received: May 06, 2014 